\title{
Oivallinen ohjenuora tutkijoille ja toimittajille
}

\author{
Urpu Strellman \& Johanna Vaattovaara (toim.) (2013). \\ Tieteen yleistajuistaminen. Gaudeamus. 281 s. ISBN 978-952-495-263-7.
}

Miten SAADA tutkimukselle julkisuutta? Entä millaisia jännitteitä tieteellisen ja yleistajuisen tekstin välillä on?

Urpu Strellmanin ja Johanna Vaattovaaran toimittamassa teoksessa Tieteen yleistajuistaminen haetaan vastauksia muun muassa näihin kysymyksiin. Teokseen on valikoitu ryhmä nimekkäitä kirjoittajia tieteen ja viestinnän eri alueilta. Kirjan 19 artikkelia antavat konkreettisia viestimisneuvoja tutkijoille ja tieteen asiantuntijoille. Siinä käydään läpi koko tieteen yleistajuistamisen kirjo tutkimusrahoituksen hakemisesta yksittäisten lehtijuttujen kirjoittamiseen, haastattelujen antamiseen, bloggaamiseen ja tietokirjan julkaisemiseen.

Viitekehyksen keskustelulle asettaa luonnollisesti yliopistojen kolmas tehtävä, joka on lisännyt paitsi tieteen asiantuntijoiden myös tiedottajien ja tiedetoimittajien ammattivaatimuksia. Kolmas tehtävä on samalla vahvistanut yksittäisten tutkijoiden vaikutusvaltaa, toteaa Tutkimuseettisen neuvoston puheenjohtaja Krista Varantola teoksen ensimmäisessä osassa, joka käsittelee tieteellisen ja yleistajuisen jännitettä ja yleistajuistamisen etiikkaa. Toinen kirjan toimittajista, Johanna Vaattovaara, opastaa erityisesti nuoria tutkijoita uran alkuvaiheen rahoitushakemusten laatimiseen ja valmiista tutkimuksesta tiedottamiseen.

Yleistajuistamisen tärkeys näyttää toimittajien mukaan olevan yhä ristiriidassa sen todellisuuden kanssa, johon esimerkiksi nuoret tutkijat tämän tästä törmäävät: aikaa on rajallisesti, joten se kannattaa laittaa popularisoinnin sijaan tieteelliseen julkaisemiseen. Teos pyrkii pehmentämään vastakkainasettelua tieteellisen ja populaarin välillä.

\section{MIETI, KENELLE KIRJOITAT}

Kirjan parasta antia ovat tietokirjailijan ja entisen päätoimittajan A.-P. Pietilän sekä suomen kielen yliopistonlehtori Toini Rahtun ja terveysviestinnän tutkija ja toimittaja Ulla Järven artikkelit teoksen toisessa ja kolmannessa osassa. Kolmen artikkelin välille muodostuva keskustelu peilaa realistisesti toisiaan tarvitsevien median ja tiedemaailman välistä suhdetta.

Rahtu johdattaa yleistajuisen kielen käyttöön kuvaamalla tieteellisen ja populaarin tekstin rakenne-eroja paikoitellen jopa varsin yksityiskohtaisesti. Hänen ydinviestinsä kuuluu: uutisessa tärkein eli tulokset nostetaan kärkeen toisin kuin tutkimuksessa, jossa johtopäätöksiin edetään kronologisessa järjestyksessä. Sekä Rahtu että Järvi ohjeistavat tekstin kirjoittajaa pohtimaan, kenelle tekstinsä suuntaa. Tämä kuvastaa hyvin myös median ja tieteen toimintalogiikan ja julkaisukriteereiden eroja. Tutkimustulosten julkaiseminen on tieteen eetoksen perusperiaatteita. Jatkuvan ajankohtaisvaateen paineessa elävä uutismaailma sen sijaan haarukoi yhteiskunnasta kiinnostavia aiheita sen perusteella, mikä vetoaa yleisöön.

A.-P. Pietilän mukaan uuden tiedon julkaiseminen on medioille vasta toissijainen kriteeri. Ensisijaisesti julkaisukynnyksen ylittävät aiheet, jotka lisäävät kyseisen median vetovoimaa yleisön silmissä ja osallistuvat johonkin ajankohtaiseen keskusteluun. Kaikilla medioilla on myös oma erityisyleisönsä, jota sen tulee tarjonnallaan palvella ja tätä kautta sitouttaa esimerkiksi lehden tilaajat eli maksavat asiakkaat pysymään uskollisina lukijoina.

\section{KIRKASTA ARGUMENTTISI}

Olisi varsin suotavaa, että media 
ja tiedemaailma ymmärtäisivät toistensa toimintaa ohjaavat periaatteet paremmin. Hyvä oivallus yleistajuistamisen paradoksaalisuudesta tulee ilmi kirjan johdannossa, jonka on laatinut venäjän kielen ja kirjallisuuden professori Arto Mustajoki. Hänen mukaansa medialle riittää paras saatavilla oleva asiantuntija. Toisin sanoen, ja toki kärjistäen, asiantuntijakommenttia juttuunsa etsivä toimittaja tarvitsee minkä tahansa lausunnon nopeasti, sillä etenkään uutistoimituksissa ei ole aikaa odotteluun. Haastattelupyyntöön vastaava asiantuntija voi kokea olevansa väärä henkilö kommentoimaan aihetta, joka ei kuulu hänen erityisosaamiseensa. Lukijan, katsojan tai kuulijan näkökulmasta on kuitenkin yhdentekevää, onko tietolähde alansa huippu vai rivitutkija.

Kuinka siis ratkaista tilanne niin, että molemmat osapuolet ovat tyytyväisiä? Kirkastamalla tutkimuksen pääargumentit suuren yleisön näkökulmasta, toteaa viestintävalmentaja Ismo Jokinen kirjan neljännessä osassa. Yleistajuinen puhuminen voi joidenkin tutkijoiden mielestä olla jopa vaikeampaa kuin kirjoittaminen, joten argumentointia on hyvä harjoitella etukäteen.

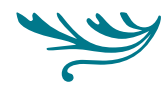

Puheviestinnän asiantuntijat Maija Gerlander ja Tuuli-Mariia Nilsson antavat neuvoja onnistuneen puhe-esityksen pitämiseen. On varsin tavanomaista, että tutkija on työskennellyt aiheen parissa vuosikausia, ja hänen pitää tiivistää olennainen puolen tai tunnin esitykseen. Tietomäärän tiivistäminen on vaikeaa, mutta samalla puhujarooli antaa mahdollisuuden erilaiseen tieteelliseen esittämiseen. Tutkija voi esimerkiksi tuoda esitykseensä omakohtaisuutta, jota tieteellisessä tekstissä tyypillisesti vältellään. Tilaisuus rakentuu vuorovaikutuksen varaan, joten se voi elää yleisön reaktioiden mukaan.

\section{JÄRJESTÄ AIKAA}

Tieteen yleistajuistaminen on ajankohtainen ja polttava kysymys, toteavat kirjan toimittajat. Filosofian tohtori ja kirjailija Tiina Raevaara kyseli taannoin Suomen Kuvalehden blogissaan, onko tieteen popularisointi nyt erityisen trendikästä? Hän muun muassa viittasi käsillä olevaan teokseen ja yleistajuistamisen kurssien suosioon korkeakouluissa, täydennyskoulutuskeskuksissa ja muissa opistoissa.

On totta, että tiedeviestinnän merkitys yhteiskunnassa kasvaa, ja samalla tarve viestinnän kou- lutukselle lisääntyy. Tämä kirja vastaa osaltaan tiedontarpeeseen. Mediayhteiskunnan nopea kehitys on avannut tutkijoille myös uudenlaisia rooleja, joissa vuorovaikutusta yhteiskunnan kanssa ei käydä enää pelkästään väliportaiden, kuten tiedetoimittajien tai tiedottajien kautta, vaan suoria vaikutuskanavia, esimerkiksi blogeja hyödyntäen.

Kirjan kirjoittamisen jälkeen Tiedonjulkistamisen neuvottelukunta (TJNK) julkisti Tiedeviestinnän toimenpideohjelman (28.2.2013), joka muun muassa patistaa korkeakouluja laatimaan yhteiskunnallisen vuorovaikutuksen laatu- ja palkitsemisjärjestelmän. Jos toimenpideohjelman lupauksen "Tiede kuuluu kaikille!" haluaa lunastaa, suosittelen ohjanuoraksi Tieteen yleistajuistamista. Kirjan lukeminen on hyödyksi paitsi tutkijoille myös viestinnän ammattilaisille. Toimittajienkin on hyvä palauttaa mieleen, mitä tieteen popularisointi vaatii asiantuntijoilta.

Annu Hattunen

julkaisupäällikkö

Kansanvalistusseura 